\title{
Language and Sex: The Relationship of Language to Behavior
}

\author{
Basel Al-Sheikh Hussein \\ Department of English and Literature, Faculty of Arts, Al-Zaytoonah Private University of Jordan, Amman, Jordan \\ Email: facultyofarts2@yahoo.com
}

\begin{abstract}
Long before linguists have focused on the role language plays in the position of women in society, they had studied and are still studying the presence of lexical, phonological, and morphological forms that are used only or predominantly by speakers of one sex or the other. Now linguists are interested in sociolinguistic variation: men's and women's speech is investigated along with social status, style, age, and ethnicity. Studies of linguistic variation related to sex in some Arab, American, and British communities reveal the fact that women are more conservative than men in their tendency to standard linguistic forms. Women are sensitive to linguistic variants that are socially stigmatized; therefore, they consistently produce forms which approach those of the standard language. And because women feel socially insecure, they are more status conscious than men are in the equivalent social roles. It follows from this that women tend more than men to use the forms of language that carry higher status connotations. In this paper, the author will attempt to investigate the hypothesis that the same holds true for sex-linked variation not only in highly sophisticated countries but also in still developing and non-developing communities which have been studied.
\end{abstract}

Index Terms - sociolinguistic variation, stigmatized, Whorfian Hypothesis, linguistic provision

\section{INTRODUCTION}

Studies on language and sex, i.e. on the relationships between sex and language, are abundant but vary in quality. These studies make up the major issue in the sociolinguistics of speech (cf. Coates 1986). Consequently, linguists were motivated to widen their studies on the connection between the structures, vocabularies, and ways of using particular languages and the social roles of the men and women who speak these languages. The focus of research since the 1970s has been on whether men and women who speak a particular language use it differently; i.e., studies have tried to answer the question 'Are the different uses of language due to its structure?' If the answer to this question positive, this would then prove the correctness of the Whorfian hypothesis that claims that the structure of language influences how its speakers view the world. This, in turn, would justify the question of whether the differences between men's and women's speech reflect the way in which they choose to deal with each other in their society.

Studies on social variables have documented that male speakers differ from female speakers in using socially disfavored variants of sociolinguistic variables more than women do. Women avoid these in favor of socially more accepted variants which are referred to by Fasold (1992) as the 'sociolinguistic gender pattern'. Examples of this pattern were also reported by Fischer (1958), who found that girls in a school used the '-in' variant of the '-ing' suffix less frequently than boys did. Since Fischer's finings, the gender pattern has been observed with some regularity.

It is possible that the consistency of the gender pattern has sometimes been overstated, but it would be wrong to ignore the evidences from sociolinguistic research that demonstrate its existence.

The author of this paper will try to explain the differences between men's and women's speech not only in the Western societies but also in other ones, like in the Jordanian society.

\section{REVIEW OF RELATED LITERATURE}

Lakoff's book 'Language and Women's Place' (1975) was the first widely influential study of the difference in language use and that led her to conclude that language used to describe women had the overall effect of submerging a woman's personal identity. That is to say, women's identities are submerged because they are not encouraged to use the means of expressing themselves strongly but only expressions and forms that express uncertainty about what they are speaking. Lakoff described some categories of language use that are sharply differentiated by the sex of the speaker: categories such as lexical distinctions (color terms), strong versus weak expletives, women's versus neutral adjectives, and tag questions. Accordingly, women, for example, are not expected to use 'strong' expletives, such as 'damn', but are encouraged to substitute weaker ones like 'oh dear'. Such a difference in language use between men and women gives men the possibility of expressing strong emotions without being punished, while women are denied this opportunity. Lakoff also notices the difference between women's and neutral adjectives. She observed that there are adjectives in English which express approval and admiration, such as 'great' and 'terrific' which are neutral in the sense that they are readily and appropriately used by either men or women. Other adjectives, like 'adorable', 'charming', and 'divine' can only be expected to be used by women, but not generally in men's speech. For Lakoff, the existence of the 
women's words used only for trivial expression suggests that what men have to say is in fact important, because a man says it. Linguistic provision is made for women only to express opinions that are seen immediately to be of no general consequence (cf. Fasold 1992).

According to Lakoff, the frequently used form of tag questions by women is also negatively interpreted by men; namely, as presenting them as unsure of their opinions and thereby as not really having opinions that count very much. So, tag question usage presents one more example of the submersion of women's individualities. Lakoff explains herself in saying that a question like 'when will dinner be ready?', women would tend to answer 'around six o'clock?'. Women would feel obliged to adjust dinner time to suit the convenience of other members of the family. Unlike them, if a man asked 'what time are we leaving for our trip tomorrow?', it would seem natural for him to reply with something like 'At 7.30 and I want everyone to be ready'.

Characteristic of Lakoff's work is that she identifies the linguistic elements which belong to women's speech to confirm that women use them more than men do. Even though Lakoff acknowledges in her later work (1977c) that the individual linguistic elements are, in a way, artifacts of the overall interactional style differences that are developed and used by men and women, Fasold (1992) criticizes her suggestion that tag questions might be a feature of women's style used to request confirmation that the hearer agrees with what she has just said. Fasold says that the question should not be 'What features are used disproportionately more or less by women than by men?' rather it is 'what differences in interactional strategy between women and med are there, and how do they reveal the structure of society with regard to the sexes?' In other words, linguists would make their contribution to the restated problem by discovering how language is used as the major tool for executing these strategies.

Scholars like Valiant (1981) criticize Lakoff's work on gender in language saying that she does not make a clear distinction between language and language use, since early in her original article (1973 a, p. 46), Lakoff anticipates her conclusions in this statement: "We will find, I think, that women experience linguistic discrimination in two ways: in the way they are taught to use language, and in the general way language use treats them". Accordingly, Lakoff seems to be dealing with matters of language use and expressing the view that, since society's changing attitudes play a crucial role in the statuses of a language, societal attitudes (including these towards women) must be included in the linguistic analysis.

However, Lakoff's disinclination to maintain a distinction between language and language use has led to a criticism on methodological grounds. As Fasold (1992) notices, Lakoff's fundamental source of data is that used in the analysis of abstract syntax. The data come from introspection based on her own speech and that of her acquaintances. The introspective method works for syntacticians precisely because they assume that sentences are to be abstracted from language use. If language use is taken as an inherent part of linguistic scholarship, it is far from clear that the introspective method is still appropriate. Some of the work Lakoff's research has inspired was motivated by a desire to base conclusions on more systematically observed and vigorously analyzed data.

The generic uses of masculine forms can also be seen as problematic. This applies to the pronoun 'he' in contexts like 'Each bicyclist must dismount and walk his bicycle across the intersection', where it is not known whether any particular bicyclist is female or male. It also applies to the word 'man', as in 'Man has learned to control his environment to an astonishing extent'.

Vatterling-Braggin (1981, Part III) expresses some doubt about whether or not this generic use of masculine forms is really generic. Many studies have been conducted on people's responses to supposedly generic uses of masculine forms. The results overwhelmingly support the conclusion that this usage has the effect of excluding women (cf. Bodine 1975; Martyna 1980; McKay and Fulkerson 1979). That is, when the pronoun 'he' is used, it will almost be heard as excluding female referents. Regardless problems concerning the generic use of masculine forms, overtones can be noticed that are associated with sex-paired words. For example, Lakoff (1973 a, 1975) makes a strong case for the euphemistic use of 'lady' as opposed to 'gentleman', as if 'woman' were an unpleasant term that ought to be avoided, in addition to bad connotations associated with the woman's term than the corresponding man's term. For instance, a 'bachelor' and a 'spinster' are both unmarried, and one is a man and the other a woman. But, unlike a bachelor who is seen as probably being unmarried by choice and living a happy life, a spinster conjures an image of an old and unappealing woman living an unfulfilled life in consequence of her failure to marry. Unlike with the woman's term, there are usually favorable implications with the man's term. A 'master' is an individual with great ability in some skilled endeavour; you would never use the word, as the word 'mistress is used, to refer to someone's regular partner in adultery (Fasold 1992, P. 113).

It is obvious for those who are interested in the relationship of language to its speakers' linguistic behavior that men's and women's reveal phonological, morphological, and lexical differences. But the differences do not result in different languages. The language with these differences remains the same for both sexes but with noticeable sex-based characteristics (cf. Taylor 1951b). Phonological differences in the speech of the two sexes have been noticed in different dialects of English. One of the earliest studies of English variation was conducted by Fischer's study of the (ng) variable (1958); for example, pronunciations like 'working' versus 'workin'.

A variety of phonological differences is also found in different dialects of Arabic. For example, Standard Arabic /K/, as in 'king, has the colloquial Jordanian Arabic reflex /ts/, as in 'church'. The use of / $\mathrm{k} / \mathrm{instead}$ of /ts/ is an attempt to approximate standard Arabic, and it carries a sociolinguistic value as to the background of the speaker. The occurrence 
of these two variants in the speech of Jordanian men and women shows that there is a significant difference between them in their use of this variable. Jordanian men and women agree that the use of the standard variant signals the high level of education of the speaker, and it would furthermore mark higher social status. In his study on women's and men's speech in Amman, Jordan, Abd-el-Jawad (1983) notices that women tend to use the standard variant more than men do, and that this because they want to show their high social status, or to give the impression of belonging to a high social class.

Concerning differences between the sexes in the area of morphology and vocabulary, there are also many studies that have focused on English and other languages. Lakoff (1973a) observed that women use color words and adjectives which are used very rarely by men, such as 'beige', 'lavender', 'adorable', 'lovely', 'divine', and 'sweet'.

As a result of the documentation of the differences between the two sexes in the area of morphology, it is now understandable why there is a frequent insistence that neutral words be used as much as possible, as in describing occupations, e.g., 'chairperson', 'salesclerk', and 'actor' in sentences like 'she is an actor'. The documentation of this kind also suggests modifications for old terms, e.g., changing 'policeman' to 'police officer', and 'chairman' to 'chairperson' (cf. Wardhaugh 1987). Certainly, there are sex differences in word choice in various languages. For example, Arab women show that they are women by using a word-final particle 'eh' or 'eton', like 'ameeneh' or 'ameeneton' (both words mean the same, namely, 'honest'), whereas men show that they are men by the use of the word 'ameen' without 'eh' or 'eton'. So, they speak of themselves as 'ameen' (honest) instead of 'ameeneh' or 'ameeneton'.

Different languages seem to prescribe different forms for use by men and women. The Yana language of California, according to Sapir (1929a), contains special forms for use in speech either by or to women. This phenomenon has been found among various aboriginal peoples of Australia, e.g., among the Zulus and Mongols.

Differences in the speech of males and females are also found in the area of grammar. For example, Lakoff (1973a) claims that women may answer a question with a statement that employs the rising intonation pattern usually associated with a question rather than the falling intonation pattern associated with making a firm statement. Lakoff says that this happens because women are less sure about themselves and their opinions than are men. For the same reason women add tag questions to statements.

Other sex-linked differences in the speech of men and women exist. Women, for example, are often named and addressed differently from men. Apparently a wider range of address terms is used them than to men. Women are more likely than men to be addressed by their first names, or by such names as 'lady', 'miss', 'dear', and even 'baby'. Women are also sometimes required to be silent in situations in which men may speak. In some societies only men are encouraged to talk on all occasions, but the ideal wife is silent in the presence of her husband, and at gatherings where men are present she should talk only in a whisper. Linguists are a ware of the fact that social factors could provide explanations for some of these differences.

\section{EXPLANATIONS FOR MEN’S AND WOMEN’s SPEECH DiFFERENCES}

Observing how men and women use language in conversations can help find some clues to explain the differences between men and women in their use of language. Men, for example, use language to talk about business, politics, and sports, whereas women speak about social life, food, and life-style. It has also been observed that when men and women interact in conversation, men tend to explain to women, whereas women tend to apologize to men. In cross-sex conversations women ask more questions than men. In addition, women view questions as part of conversational maintenance and men primarily as requests for information. Women tend to discuss, share, and seek reassurance, and men tend to look for solutions and to give advices.

Obviously, men and women in their conversations reveal the normal power relationship that exists in society, with men dominant and women subservient. Maltz and Borker (1982) propose that this is because of the fact that men and women came from different sociolinguistic subcultures. They have learned to do different things with language, particularly in conversation, and when the two sexes try to communicate with each other, the result may be miscommunication. Maltz and Broker conclude that men and women observe different rules in conversing and that in cross-sex talks the rules often conflict. In this view men and women have been brought up to behave differently with regard to language. Lakoff (1973a, p.48) has commented as follows: "The ultimate effect... is that women are systematically denied access to power, on the grounds that they are not capable of holding it as demonstrated by their linguistic behavior along with other aspects of their behavior; and the irony here is that women are made to feel that they deserve such treatment, because of inadequacies in their own intelligence and / or education. But in fact it is precisely because women have learned their early lessons so well that they later suffer such discrimination".

Most of the explanations for the differences in men's and women's use of language were directed at explaining the linguistic behavior of women. Women choose the language they choose because their social status is judged by how they behave linguistically. The approximation of women to the standard variety spoken in the capital of Jordan, Amman, for example, is evident in their use of lexical items associated with it and their avoidance of the non-standard varieties which seem to be socially stigmatized. Jordanian women living in Amman tend to use features from the prestigious linguistic variety in their speech, because they feel that this variety is associated with high social status. This general impression was obvious by the responses of a sample of men and women whose linguistic attitude was checked. They 
agreed that women tend to use features from the dialect spoken in Amman more than men do (cf.Abd-el-Jawad 1983). M.R. Key (1975) also suggests that women use favored linguistic forms as a way of achieving status through the use of linguistic features. He says that "It would appear, then, that women have not universally accepted the position in the lower ranks, and that, out-of-awareness, and in a socially acceptable and non-punishable way, women are rebelling" (P.103) . In his overview of linguistic sex differentiation, Trudgill (1983a, PP. 167-8) provides a series of related explanations. He writes: "Women are more closely involved with child-rearing and the transmission of culture, and are therefore more aware of the impotence, for their children, of the acquisition of (prestige) forms"...

"The social position of women in our society has traditionally been less secure than that of men. It may be, therefore, that it has been more necessary for women to secure and signal their social status linguistically and in other ways, and they may for this reason be more aware of the importance of this type of signal".

From what was said so far we can infer that the problem of the differences between men's and women's speech is not a linguistic problem but a cultural one. The problem reflects the fact that men and women are expected to have different interests and different roles, to hold different types of conversations, and to react differently to other people. Men and women use language to achieve certain purposes, and so long as sexual difference is equated with differences in access to power and influence in society, such differences can be expected to result in linguistic differences. Power and influence, for both men and women, are also associated with education and social class. That sex differences in language may be social in origin rather than linguistic can be reinforced in a study of norms and norm-breaking in Malagasy by Keenan (1974) according to whom men do not put others into situations in which they may lose face. People in Malagasy try to maintain good communication in their relationships and avoid confrontations. They prefer indirectness as an expression of respect; men's "requests are typically delayed and inexplicit, accusations imprecise, and criticisms subtle "(Kneenan 1974, P.141). Unlike men, women in Malagasy openly and directly express their feelings toward others. They can be direct and straight. In the Malagasy society, then, it is the men who are indirect and the women who are direct. In the Malagasy society indirectness is surprisingly prized and regarded as traditional and it is the men who employ it. On the other hand, "direct speech...is associated with a loss of tradition", and it is found among women and children (Keenan, P.142). Women are definitely inferior to men in this society too, for "Where subtlety and delicacy... are required in social situations, men are recruited", but "where directness and explicitness.. are desirable in social situations, women are recruited" (ibid, p.143). Here we can see how the speech of the two sexes reflects their relationship within the total society. These evidences suggest that men and women differ in the kinds of language they use and how they use it because men and women often fill distinctly different roles in society. There seems to be some evidence to support the claim that the greatest differences appear to exist in societies in which the roles of men and women are most clearly differentiated. And in societies in which men's and women's roles are less clearly differentiated, we may expect to find a reflection of this situation in the language that is used. Most of these differences can be explained by the different positions men and women fill in society. Men have more power; women tend to be aspired to a different and better place. Therefore, women appear to be more conscious of uses of language which they regard as being socially superior.

\section{CONCLUSION}

Sex-differences are reflected in language, and some emphasis in research on language and sex has to do with certain linguistic features that women use, apparently in response to dominance by men. These features have been seen as reflecting 'female register' which is closely related to the study of cross-sex conversation. To some extent, the results of conversational research provide explanations for the features of female register.

Another aspect of language and sex raised by Lakoff is the matter of how language refers to women and men. A central issue in this area is the so-called 'generic masculine', in which compounds are supposed to refer to people of both sexes when the sex of the referents is not known. Besides the supposedly generic use of masculine forms, sexrelated differences emerge in the case of pairs of words which are denotatively the same. Almost always, there are connotations associated with the female-referring item that are either euphemistic ('lady' compared to 'gentleman'), or detrimental to women ('witch' versus 'warlock'), often imputing sexual immorality to the female referent ('mistress' versus 'master').

Many studies on language and sex suggest that men's and women's speech differs because boys and girls are brought up differently, and men and women often fill different roles in society. However, men and women know this and react in different ways, for example seeking 'prestige' differently. Women prefer 'overt' prestige and men 'covert' variety.

The author will conclude his paper with the claim that it is possible to free language from whatever is 'sexist' in it thorough child-rearing practices and role differentiations which are less sexist.

\section{REFERENCES}

[1] Abd-el-Jaead, H. (1983). Sex Differentiation and Linguistic Variations, a Case Study: Spoken Arabic in Amman. In J.Owens and I. Abu-Salim eds., Proceedings of the Second Annual Linguistic Conference. Department of English, Jordan - Yarmuk University, PP. 101-20.

[2] Bodine, A. (1975). Androcentric in Prescriptive Grammar: Singular "they", Sex-indefinite "He" and "He or She". Language and Society, 4, PP. 129-46. 
[3] Butler, J. (1990). Gender Trouble: Feminism and Subversiton of Identity. New York and London: Routledge.

[4] Coates, J. (1986). Women, Men and Language. London: Longman.

[5] Erlich, S. and King, R. (1998). "Gender-based Language Reform and the Social Construction of Meaning", in The Feminist Critique of Language, $2^{\text {nd }}$ Edition, Cameron, D. (ed.), London and New York: Routledge, PP. 164-79.

[6] Fasold, R. (1992). The Sociolinguistics of Language. Oxford: Basil Blackwell Publishers.

[7] Fausto-Sterling, A. (1992). Myths of Gender. NY: Basic Books.

[8] Fischer, J. (1958). Social Influences on the Choice of a Linguistic Variant. Word, 14, PP .47-56.

[9] Keenan, E. (1974). Norm-makers, Norm-breakers: Uses of Speech by Men and Women in a Malagasy Community. In Bauman, R. and Sherzer, J.(eds.) (1974) ; Exploration In the Ethnography of Speaking. London: CUP.

[10] Key, M.R. (1975). Male / Female Language. Metuchen. NY: Scarecrow Press.

[11] Labov, W. (1966). The Social Stratification of English in New York City. Washington, DC: Center for Applied Linguistics.

[12] Lakoff, R. (1973a). Language and Women's Place. Language in Society, 2, PP. 45-80.

[13] Lakoff, R. (1975). Language and Women's Place. New York: Harper and Row.

[14] Lakoff, R. (1977c). Women's Language and Style, 10 (4), PP. 22-47.

[15] Maltz, D.N. and Borker, R.A. (1982). A Cultural Approach to Male-Female Miscommunication. In Gumperz, J. (182b); Discourse Strategies. Cambridge: CUP.

[16] Martyna, W. (1980). The Psychology of the Generic Masculine. In McConnell-Ginet, Borker and Furman 1980, PP.69-78.

[17] Mckay, D. and Fulkerson, D. (1979). On the Comprehension and Production of Pronouns. Journal of Verbal Learning and Verbal Behavior, 18, PP. 661-73.

[18] Mills, S. (2008). Language and Sexism. Cambridge: CUP.

[19] Sapir, E. (1929a). Male and Female Forms of Speech in Yana. In S.W.J. Teeuwen (ed.), Donum Natalicum Schrijnen. Najmegen: Dekker and Van de Vegt.

[20] Saul, J. (2003). "Feminism and Language Change", Feminism: Issues and Arguments. Oxford: OUP, PP. 170-98.

[21] Taylor, D. (1951b). Sex Gender in Central American Carib. International Journal of American Linguistics, 17 (2), PP. $102-4$.

[22] Trudgill, P. (1946). The Social Differentiation of English in Norwich. London: CUP.

[23] Trudgill, P. (1975). Sex, Covert Prestige, and Linguistic Change in the Urban British English of Norwich. In B. Thorne and N.Henley (eds.), Language and Sex: Difference and Dominance. Newbury House.

[24] Trudgill, P. (1983a). On Dialect. Oxford: Basil Blackwell Publishers.

[25] Valian, V. (1981). Linguistics and Feminism. In Vetterling - Braggin 1981, PP. 68-81.

[26] Vetterling-Braggin, M. (1981). Sexist Language. Totowa, NJ: Rowman and Littlefield.

[27] Wardhaugh, R. (1983). An Introduction to Sociolinguistics. Oxford: Basil Blackwell Publishers.

[28] Zimmerman, D.H. and C. West (1975). Sex Roles, Interruptions and Silences in Conversation. In Thorne, B. and Henley, N(eds.) (1975);Language and Sex: Difference and Dominance. Rowley. MA: Newbury House.

Basel Al-Sheikh Hussein was born in Burqa/Jordan 1947. He received his MA in Linguistics from Goethe University/W.Germany (1980), whereas PhD degree in Linguistics (1985). Over the past 20 years he was teaching linguistics to Arab Students in University of Basrah, Takreet University (Iraq) and in Al-Zaytoonah University, Al-Zarqa University and Al-Isra University (Jordan). Since then, he has been doing research in the field of linguistics, sociolinguistics and applied linguistics.

Dr. Basel Al-Sheikh Hussein is currently an Assistant Prof. of English Linguistics, Al-Zaytoonah University of Jordan/College of Arts/Dept. of English. 